\title{
Absence of isozyme variation in geographically isolated populations of the land snail Chondrina clienta
}

\author{
Bruno Baur* $\dagger$ and \\ Matthias Klemm
}

\author{
* Department of Zoology, Uppsala University, Box \\ 561, S-751 22 Uppsala, Sweden. \\ $\ddagger$ Zoologisches Institut, Universität Tübingen, Auf der \\ Morgenstelle 28, D-7400 Tübingen, Federal Republic \\ of Germany.
}

\begin{abstract}
Genetic differentiation of the rock-dwelling land snail Chondrina clienta was examined by enzyme electrophoresis in five isolated populations of an outlying area (the Baltic island of Öland, Sweden), and in one population from the species' main range (eastern Alps, Austria). Patterns of allelic variation were compared for 17 putative gene loci involving ten protein systems. All individuals from the five isolated populations on Öland were identically homozygous at all gene loci assayed. Snails from the eastern Alps were homozygous and allelically identical, but they differed by one isozyme band that was absent in animals from Oland and by different alleles fixed at three loci. The absence of isozyme variation and anatomical evidence indicate that self-fertilization may be the prevailing type of reproduction in $C$. clienta. The allelic identity of the five populations on Öland suggests that they were derived from a single strain, the origin of which probably consisted of one or few self-fertilizing individuals which colonized the island.
\end{abstract}

\section{INTRODUCTION}

The genetic differentiation of island populations is affected by propagule size, arrival time of founders, genetic structure, breeding system, reproductive rate, generation time, and rate of gene flow and selection (Baker and Stebbins, 1965; Endler, 1977; Berry, 1986). Theoretical and empirical evidence suggest that genetic bottlenecks over several generations and the mating system are the most important factors for differentiation among populations (Nei et al., 1975; Williamson, 1981; Wool, 1987). It is often assumed that founder events can lead to a substantial reduction of genetic variation in island populations, and that changes in allelic frequencies provide opportunities for speciation (Mayr, 1963; Carson, 1984). However, it is still not clear how important founder events are in real populations (Barton and Charlesworth, 1984). Determining the impact of founder events is difficult, because the dynamic process of genetic differentiation can rarely be followed in nature and only the present level of differentiation of island populations can be examined and compared with that of putative source populations.

Chondrina clienta (Westerlund) is a rock-dwelling land snail which has a disjunct distribution as

$\dagger$ Present address: Zoology Institute, Basel University, Rheinsprung 9, CH-4051 Basel, Switzerland. it occurs far from its main range in central and southeastern Europe on the Baltic islands of Öland and Gotland and at one site on the Swedish mainland (fig. 1) (Kerney et al., 1983; Gittenberger, 1984; Waldén, 1984). It has been surmised that $C$. clienta colonized these remote areas in Scandinavia from continental sources during the Boreal or Subboreal warm periods (8800-7500 and 47002800 years B.P., respectively) (Proschwitz, 1977; Waldén, 1986). On the island of Öland, the present-day distribution of $C$. clienta is patchy: changes in agricultural methods over the last century have fragmented the habitat of the species (heathlike grassland with exposed rock surfaces), and thereby increased the isolation of snail populations (Königsson, 1968; Rosén, 1982; Baur, 1988).

Here we compare genetic variation in five isolated populations of $C$. clienta from the island of Öland with that from a population of the eastern Alps (the species' main range) by assaying electrophoretic variation of enzymes.

\section{MATERIALS AND METHODS}

\section{The species}

Chondrina clienta has a cylindro-conical shell with an adult height ranging from 5.5 to $7.0 \mathrm{~mm}$ 


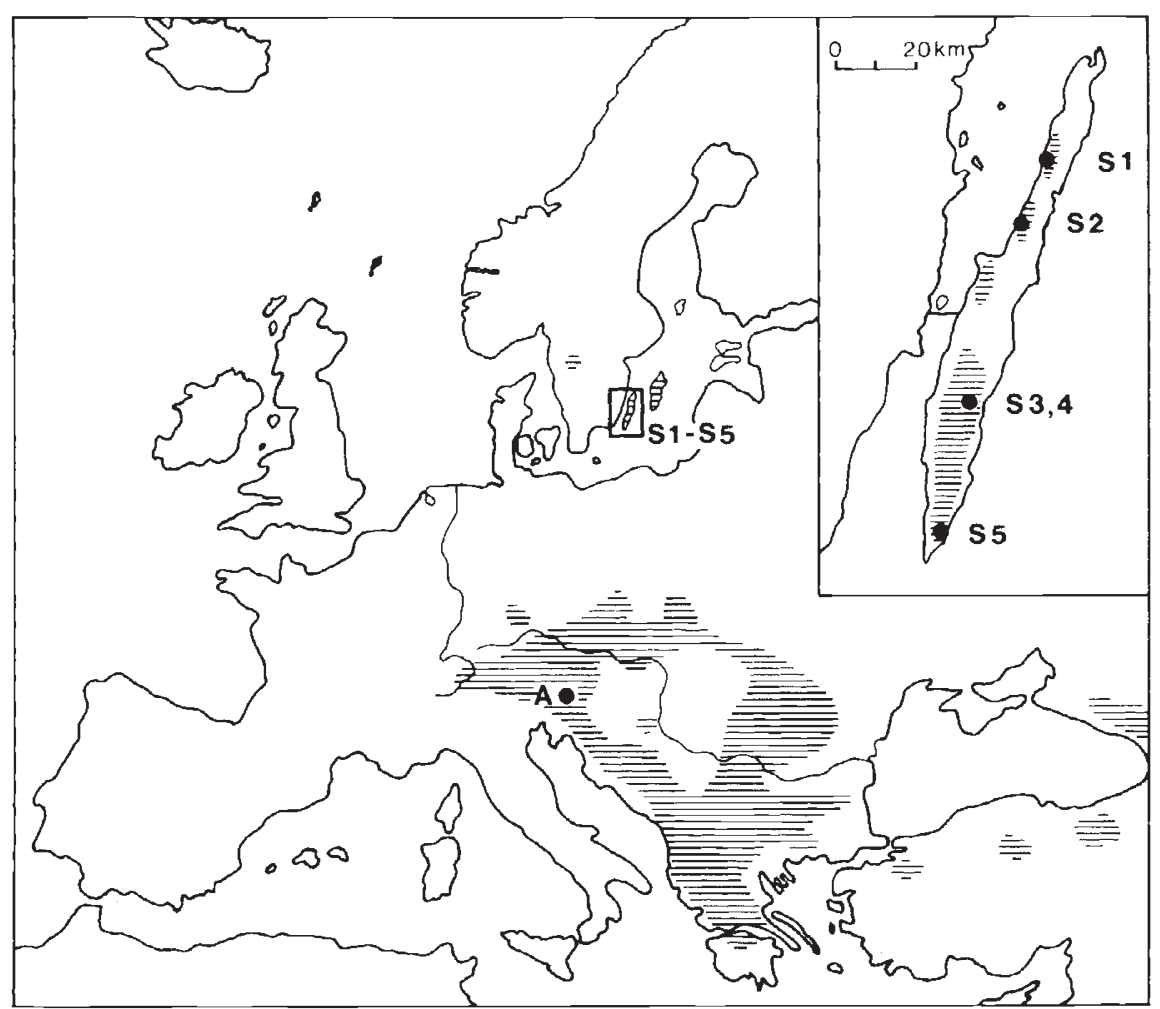

Figure 1 Distribution of C. clienta and sampling sites of our study. Hatching indicates the recent range of $C$. clienta (the occurrence in the Caucasus is beyond the eastern limit of the map) (after Kerney et al., 1983; Gittenberger, 1984; Walden, 1984). $\mathrm{S}_{1}-\mathrm{S}_{5}$ refer to the sampling sites on Öland (Sweden) and A to that in the eastern Alps (Austria).

(Kerney et al., 1983; Baur, 1988). Confined to very special environment, it occurs in open limestone habitats, such as exposed rock-surfaces, stone walls and piles of stones (Kerney et al., 1983; Gittenberger, 1984; Baur, 1987). The snails are particularly well adapted to rocky habitats; they exhibit a high resistance to drought (cf. Neuckel, 1981), and a specialized radula enables them to graze lichens from rock-faces (Schmid, 1929; Gittenberger, 1973; Breure and Gittenberger, 1982). The type of reproduction in C. clienta is unknown.

Specimens were collected from five sites (referred to as $\mathrm{S}_{1}-\mathrm{S}_{5}$ ) on the Baltic island of Öland (Sweden) in April 1987 and from one site (site A) in the eastern Alps (Austria) in August 1987 (fig. 1): $\mathrm{S}_{1}$ : Sandvik. Weathered limestone rocks at the edge of a quarry.

$\mathrm{S}_{2}$ : Gullehamn. Calcareous stone pile adjacent to a water-filled quarry, $20 \mathrm{~km}$ south of $S_{1}$.

$\mathrm{S}_{3}$ : Frösslunda. Stone wall made of flat pieces of lime stone, in the heath-grassland of Stora Alvaret, $45 \mathrm{~km}$ south of $\mathrm{S}_{2}$.
$\mathrm{S}_{4}$ : Frösslunda. Stone pile, consisting mainly of calcareous rocks, separated by a $10 \mathrm{~m}$ belt of grass and herbs from the stone wall making up site $\mathrm{S}_{3}$.

$\mathrm{S}_{5}$ : Enetri. Stone pile, consisting mainly of calcareous rocks, surrounded by arable land, $35 \mathrm{~km}$ south of $\mathrm{S}_{3}$ and $\mathrm{S}_{4}$.

A: Near Villach (Austria; 46 $36^{\prime} \mathrm{N}, 1^{\circ} 50^{\prime} \mathrm{E}$ ). South-facing dolomite rocks in a spruce forest (1100 m a.s.1.). Approximately $1200 \mathrm{~km}$ south of the sites on Öland.

At each site 70-100 fully-grown $C$. clienta were collected from an area of $5-30 \mathrm{~m}^{2}$.

\section{Electrophoresis}

Individual snails were homogenized in cooled $\left(4^{\circ} \mathrm{C}\right) 1.5 \mathrm{ml}$ Eppendorf tubes containing $30 \mu \mathrm{l}$ homogenization buffer $(20 \mathrm{mM}$ Tris- $\mathrm{HCl} \mathrm{pH} \mathrm{7.4,}$ $2 \mathrm{mM}$ EDTA, 2 per cent Triton-X-100, $2 \mathrm{mM}$ Dithiothreotol (Schlegel, 1985)). After $20 \mathrm{~min}$. lysis at $4^{\circ} \mathrm{C}$ the homogenate was centrifuged at 
Table 1 Enzymes assayed and buffer systems used in the study of isozyme variation in Chondrina clienta

\begin{tabular}{|c|c|c|}
\hline Enzyme & E.C. no. & Electrophoretic buffer* \\
\hline Cytochrome- $b_{5}$-reductase (Dia) & 1.6.2.2 & TEB $8 \cdot 2$, TM 8.0 \\
\hline Esterase ( $\alpha$-Naphtylacetate) $($ Est $)$ & 3.1 .1 & TEB $8 \cdot 2$, TP $7 \cdot 0$ \\
\hline$\alpha$-Glycerophosphatedehydrogenase ( $\alpha-G p d h)$ & 1.1 .1 .8 & TM $8 \cdot 8$ \\
\hline Hydroxybutyratedehydrogenase $(H b d h)$ & 1.1.1.30 & TM $7 \cdot 4$, TM $8 \cdot 8$ \\
\hline Isocitratedehydrogenase $(I d h)$ & 1.1 .1 .42 & TC $6 \cdot 3$, TC $8 \cdot 6$, TEB $8 \cdot 2$, TM 8.8 \\
\hline Malic enzyme $(\mathrm{Me})$ & 1.1.1.40 & TM $8 \cdot 2$ \\
\hline Peptidase (1-Leucyl-1-Leucine) (Pep) & 3.4 & TEB $8 \cdot 2$, TP $7 \cdot 0$ \\
\hline Phosphoglycoisomerase (Pgi) & 5.3.1.9 & TC $6 \cdot 3$, TC $8 \cdot 6$, TM $8 \cdot 8$ \\
\hline Phosphoglucomutase ( Pgm) & 2.7.5.1 & TC $6 \cdot 3$, TM 8.8 \\
\hline Superoxide dismutase (Sod) & 1.15 .11 & TC-LiOH $8 \cdot 2$ \\
\hline
\end{tabular}

* TEB $8.2=0.5 \mathrm{M}$ tris $-0.02 \mathrm{M}$ EDTA $-0.65 \mathrm{M}$ boric acid, pH 8.2, Gel $1: 9 ;$ TC $6.3=0.223 \mathrm{M}$ tris $-0.086 \mathrm{M}$ citric acid, pH 6.3, Gel $1: 27$; TC $8.6=0.094 \mathrm{M}$ tris $-0.0235 \mathrm{M}$ citric acid, pH 8.6, Gel $1: 5 ;$ TM 7.4/TM 8.0/TM $8 \cdot 2 / \mathrm{TM} 8 \cdot 8=0.1 \mathrm{M}$ tris $-0 \cdot 1 \mathrm{M}$ maleic acid-0.01 M EDTA-0.01 $\mathrm{M} \mathrm{MgCl}_{2}$, pH adjusted with $1 \mathrm{M} \mathrm{NaOH}$, Gel 1:9; TP $7.0=0.09 \mathrm{M}$ tris $-0.12 \mathrm{M} \mathrm{NaH}_{2} \mathrm{PO}_{4}$, Gel 1:10; TC-LiOH $=0.19 \mathrm{M}$ boric acid $-0.03 \mathrm{M} \mathrm{LiOH}$, $\mathrm{pH} 8.2$, Gel $0.045 \mathrm{M}$ tris $-0.0072 \mathrm{M}$ citric acid $-0.019 \mathrm{M}$ boric acid $-0.003 \mathrm{M}$ LiOH.

$10,000 \mathrm{~g}$ for $15 \mathrm{~min}$. The supernatant was immediately used for electrophoresis or stored at $-70^{\circ} \mathrm{C}$. Electrophoresis was carried out at approximately $5^{\circ} \mathrm{C}$ using horizontal 12 per cent starch gels $(220 \times$ $150 \times 10 \mathrm{~mm}$, Sigma-Starch and Connaught-Starch in proportions of $1 \cdot 46: 1$ ) with an electric output adjusted to 10-12 Watt (for buffer systems see table 1). Techniques of starch gel electrophoresis and enzyme staining are as described by Shaw and Prasad (1970), Selander et al. (1971), Schlegel (1985) and Klemm (1988).

Fifteen enzyme systems were tested; ten systems representing 17 putative gene loci were stainable (table 1).

\section{RESULTS}

All individuals in the samples from the five populations on Öland were homozygous and allelically identical at all putative gene loci assayed (table 2 ). This suggests that all populations of $C$. clienta investigated on Öland represent a single strain.

Similarly, no electrophoretical variation could be found in individuals from the Austrian population; all snails were homozygous and allelically identical (table 2). However, snails from this population were characterized by the fast migrating isozyme Dia-2 absent in animals from Öland and by different alleles fixed at the Dia-1, Est-2 and Pep-1 loci.

Since there was no variation within populations, the mean heterozygosity was zero in all six populations. The mean genetic identity (I) between snails on Öland and those in the eastern Alps was 0.813 (according to Nei (1972); calculation based on the 16 loci in common).

\section{DISCUSSION}

Our study shows no electrophoretic variation within and among five populations of $C$. clienta on Öland. Although only 30 to 50 per cent of the variation at the DNA level can be detected by enzyme electrophoresis (Lewontin, 1974; Johnson, 1977; Selander and Whittam 1983), it does appear that the level of genetic variability in C. clienta is low.

Table 2 Distribution of genotypes in $C$, clienta from five populations on Öland (Sweden) $\left(S_{1}-S_{5}\right)$ and from one population in the eastern Alps (A). The figures give the number of individuals assayed for each enzyme loci

\begin{tabular}{|c|c|c|c|c|c|c|c|}
\hline \multirow[b]{2}{*}{ Enzyme } & \multirow[b]{2}{*}{ Genotype* } & \multicolumn{2}{|c|}{ Population } & \multirow[b]{2}{*}{$\mathrm{S}_{3}$} & \multirow[b]{2}{*}{$\mathrm{S}_{4}$} & \multirow[b]{2}{*}{$\mathrm{S}_{5}$} & \multirow[b]{2}{*}{ A } \\
\hline & & $\mathrm{S}_{1}$ & $\mathrm{~S}_{2}$ & & & & \\
\hline \multirow[t]{2}{*}{ Dia-1 } & 100 & 25 & 25 & 31 & 17 & 33 & 0 \\
\hline & 20 & 0 & 0 & 0 & 0 & 0 & 27 \\
\hline Dia-2 & 100 & 0 & 0 & 0 & 0 & 0 & 27 \\
\hline Est-1 & 100 & 20 & 20 & 26 & 15 & 33 & 27 \\
\hline \multirow[t]{2}{*}{ Est-2 } & 100 & 20 & 20 & 26 & 15 & 33 & 0 \\
\hline & 95 & 0 & 0 & 0 & 0 & 0 & 27 \\
\hline Est-3 & 100 & 20 & 20 & 26 & 15 & 33 & 27 \\
\hline Est-4 & 100 & 20 & 20 & 26 & 15 & 33 & 27 \\
\hline$\alpha-G p d h$ & 100 & 10 & 10 & 10 & 10 & 18 & 10 \\
\hline$H b d h-1$ & 100 & 10 & 10 & 15 & 15 & 18 & 10 \\
\hline$H b d h-2$ & 100 & 10 & 10 & 15 & 15 & 18 & 10 \\
\hline$H b d h-3$ & 100 & 10 & 10 & 15 & 15 & 18 & 10 \\
\hline$I d h$ & 100 & 28 & 28 & 31 & 12 & 33 & 24 \\
\hline $\mathrm{Me}$ & 100 & 5 & 5 & 5 & 5 & 13 & 10 \\
\hline \multirow[t]{2}{*}{ Pep-1 } & 100 & 20 & 20 & 20 & 20 & 20 & 0 \\
\hline & 80 & 0 & 0 & 0 & 0 & 0 & 27 \\
\hline Pep-2 & 100 & 20 & 20 & 20 & 20 & 20 & 27 \\
\hline$P g i$ & 100 & 28 & 28 & 25 & 10 & 25 & 24 \\
\hline Pgm & 100 & 18 & 18 & 22 & 22 & 31 & 24 \\
\hline Sod & 100 & 20 & 20 & 20 & 10 & 10 & 24 \\
\hline
\end{tabular}

* Designation of genotypes relative to the fastest band front. 
Of all the factors determining the genetic structure of a population, none has a more profound effect than the breeding system (reviewed by Mather, 1973). Gastropods display a great variety of breeding systems, ranging from obligate outcrossing to frequent (if not obligate) self-fertilization and including parthenogenesis (Duncan, 1975; Fretter, 1984; Geraerts and Joosse, 1984; Tompa, 1984). The degree of allozyme variation is a strong indicator of the type of breeding system employed (e.g., Selander and Ochman, 1983; Brown and Richardson, 1988). Anatomical investigations indicate that $C$. clienta is aphallic in Austrian populations (Gittenberger, 1973, personal communication). In samples collected on Öland most of the individuals were aphallic (Klemm, unpubl. data). The absence of male copulatory organs in stylommatophoran snails indicates selffertilization (or, alternatively, some type of parthenogenesis) as the exclusive breeding system (Duncan, 1975; Tompa, 1984). Is the absence of heterozygosity in $C$. clienta a result of obligate self-fertilization? Although we cannot rule out the possibility of an occasional outcrossing event, our evidence indicates that the amount of outcrossing in this species is very low.

Dispersal in $C$. clienta averaged 1 to $3 \mathrm{~m}$ per year, depending on type of habitat (stone pile or limestone pavement) (Baur, 1988). The five populations on Öland are spread over $100 \mathrm{~km}$ and thus are geographically isolated from each other. Since dispersal is restricted to stony habitats (Baur, 1988), even the two populations at Frösslunda might be isolated from each other. Owing to the low vagility of $C$. clienta, the present-day distribution of the species on Öland cannot be explained by subsequent active dispersal. It is likely that the foundation of new populations has been facilitated by accidental transport, by wind, water, birds or humans ( $c f$. ., Rees, 1965). The genetic structure of the Öland populations suggests that they all derive from a single strain. Supralittorinal deposits give evidence that $C$. clienta originally occurred also at the Estonian coast of the Baltic, where the species is now extinct (Schlesch, 1958). However, our data allow no conclusions about the origin of the Öland populations.

The lack of within-population heterozygosity in C. clienta is consistent with its probable breeding system. Nevertheless, the fact that five populations of C. clienta, separated by as much as $100 \mathrm{~km}$, are identically monomorphic at 16 putative loci is a problem. We might expect mutation, natural selection, and drift to have fixed different alleles in isolated populations. Nei and $\mathrm{Li}$ (1975) developed a method for estimating the probability of allelic monomorphism under the neutral mutation hypothesis. Using their model and assuming initial gene frequencies of one, population sizes of 10,000 , and a mutation rate of $10^{-7}$, which seems reasonable for electrophoretically detectable variation (Nei 1987), the probability of five isolated populations remaining identically monomorphic at 16 loci after 2500 generations is $0 \cdot 30$ (generation time of $C$. clienta is assumed to be three years; cf. Baur 1988). Thus, identical monomorphism among the five C. clienta populations on Öland is not unlikely. Empirical data also indicate that differentiation of isolated populations may require many thousands of generations. For example, Fowler and Morris (1977) were unable to detect any genetic variation in four widely separated populations of Pinus resinosus and postulated that mutation has not had sufficient time to reestablish heterozygosity in the approximately 20,000 years since an assumed bottleneck. Similarly, the populations of C. clienta on Öland have probably not had enough time since separation to incorporate different alleles. Due to the Pleistocene glaciation, populations on Öland cannot have existed for more than about 8000 years (Proschwitz, 1977; Waldén, 1986).

The apparent absence of genetic variation is unusual. For example, of 178 vascular plant species surveyed, only four $(2 \cdot 2$ per cent) completely lacked genetic variation (Hamrick et al., 1979; Hamrick, 1983; Ellstrand and Roose, 1987; Lesica et al., 1988). By contrast, of 57 species of terrestrial gastropods surveyed, nine $(15.8$ per cent $)$ completely lacked genetic variation, namely six slug and three snail species (Foltz et al., 1982, 1984: Selander and Ochman, 1983; Boato, 1988; Brown and Richardson, 1988; this study). One of the snail species, Rumina decollata, is an obligate selffertilizer, and a very successful immigrant in the southern United States (Selander and Kaufman, 1973; Selander et al., 1974; Selander and Hudson, 1976), whereas C. clienta, another snail species with no enzyme variation, has narrow habitat requirements and a restricted range of distribution (cf., Kerney et al., 1983).

Attempts to relate the frequency of selfing to factors such as niche breadth, habitat complexity and stability have been relatively inconclusive (e.g., Foltz et al., 1984; Loveless and Hamrick, 1984; Nevo et al., 1984; Lavie and Nevo, 1986). However, self-fertilizing species are likely to have an enhanced probability of colonization success and are able to reproduce even in absence of mating partners (Baker and Stebbins, 1965; 
Tomlinson, 1966; Ghiselin, 1969; Baur and Bengtsson, 1987).

Snails from the Austrian population were also homozygous and allelically identical, but differed from the snails on Öland in three out of the 17 putative loci assayed. Inclusion of populations from the Baltic island of Gotland and of further populations from the species' main range (eastern Alps) would be particularly interesting in future studies of the possible path of colonization of $C$. clienta. Furthermore, a thorough study of the species breeding system, using cytological methods and breeding experiments is needed. While this study provides only an introductory look at the genetic variation in $C$. clienta, it shows that more detailed studies are warranted for determining the geographical scale and connectedness of the distinct strains within this species.

Acknowledgements We thank the staff at the Ecological Research Station of Uppsala University on Öland for their hospitality, and H. C. Prentice, S. C. Stearns and S. Ulfstrand for comments on the manuscript. Financial support was received from the Swiss National Science Foundation (BB) and the Reinhold and Maria Teufel Stiftung (MK).

\section{REFERENCES}

BAKER, H. G. AND STEBbins, G. L. 1965. The Genetics of Colonizing Species. Academic Press, New York.

BARTON, N. H. AND CHARLESWORTH, B. 1984. Genetic revolutions, founder effects, and speciation. Ann. Rev. Ecol. Syst., 15, 133-164.

BAUR, B. 1987. Richness of land snail species under isolated stones in a karst area on Öland, Sweden. Basteria, 51, 129-133.

BAUR, B. 1988. Microgeographical variation in shell size of the land snail Chondrina clienta. Biol. J. Linn. Soc., 35, 247-259.

BAUR, B. AND BENGTSSON, J. 1987. Colonizing ability in land snails on Baltic uplift archipelagos. J. Biogeogr., 14, 329341.

BERRY, R. J. 1986. Genetics of insular populations of mammals, with particular reference to differentiation and founder effects in British small mammals. Biol. J. Linn. Soc., 28, 205-230.

BOATO, A. 1988. Microevolution in Solatopupa land snails (Pulmonata, Chondrinidae): genetic diversity and founder effects. Biol. J. Linn. Soc., 34, 327-348.

BREURE, A. S. H. AND GITTENBERGER, E. 1982. The rockscraping radula, a striking case of convergence (Mollusca). Neth. J. Zool, 32, 307-312.

BROWN, K. M. AND RICHARDSON, T. M. 1988. Genetic polymorphism in gastropods: a comparison of methods and habitat scales. Am. Malacol. Bull., 6, 9-17.

CARSON, H. L. 1984. Genetic revolutions in relation to speciation phenomena: the founding of new populations. Ann. Rev. Ecol. Syst., 15, 97-131.

DUNCAN, C. J. 1975. Reproduction. In Fretter, V. and Peake, J. (eds.) Pulmonates, Vol, 1, Academic Press, London, pp. 309-365.
Ellstrand, N. C. AND RoOSE, M. L. 1987. Patterns of genotypic diversity in clonal plant species. Amer. J. Bot., $74,123-131$.

ENDLER, J. A. 1977. Geographic Variation, Speciation and Clines. Princeton University Press, Princeton, New Jersey.

FOLTZ, D. W., OCHMAN, H., JONES, J. S., EVANGELISTI, S. M. AND SELANDER, R. K. 1982. Genetic population structure and breeding systems in arionid slugs (Mollusca: Pulmonata). Biol. J. Linn. Soc., 17, 225-241.

FOLTZ, D. W., OCHMAN, H. AND SELANDER, R. K. 1984. Genetic diversity and breeding systems in terrestrial slugs of the families Limacidae and Arionidae. Malacologia, 25, 593605.

FOWLER, D. P. AND MORRIS, R. W. 1977. Genetic diversity in red pine: Evidence for low genetic heterozygosity. Can. J. Forest Res., 7, 343-347.

FRETTER, V. 1984. Prosobranchs. In Tompa, A. S., Verdonk, N. H. and van den Biggelaar, J. A. M. (eds.) The Mollusca, Vol. 7, Reproduction. Academic Press, New York, pp. 145.

GERAERTS, W. P. M. AND JOOSSE, J. 1984. Freshwater Snails (Basommatophora). In Tompa, A. S., Verdonk, N. H. and van den Biggelaar, J. A. M. (eds.) The Mollusca, Vol. 7, Reproduction. Academic Press, New York, pp. 141-207.

GHISELIN, M. T. 1969. The evolution of hermaphroditism among animals. Quart. Rev. Biol., 44, 189-208.

GitTenberger, E. 1973. Beiträge zur Kenntnis der Pupillacea III. Chondrininae. Zool. Verh. Leiden, 127, 1-267.

GITTENBERGER, E. 1984. Vicariantists and dispersalists among the Chondrininae. In Solem, A. and van Bruggen, A. C. (eds.) World-wide snails: Biogeographical studies on nonmarine Mollusca, Brill, Leiden, pp. 56-69.

HAMRICK, J. L, 1983. The distributions of genetic variation within and among natural plant populations. In C. M. Schönewald-Cox, S. M. Chambers, B. MacBryde and L. Thomas (eds.) Genetics and Conservation, Benjamin Cummings, Menlo Park, California, pp. 335-348.

HAMRICK, J. L., LINHART, Y. B. AND MITTON, J. B. 1979. Relationships between life history characteristics and electrophoretically detectable genetic variation in plants. Ann. Rev. Ecol. Syst., 10, 173-200.

JOHNSON, G. B. 1977. Assessing electrophoretic similarity. The problem of hidden heterogeneity. Ann. Rev. Ecol. Syst., 8, 309-328.

KERNEY, M. P., CAMERON, R. A. D. AND JUNGBLUTH, J. H. 1983. Die Landschnecken Nord- und Mitteleuropas. Parey Verlag, Hamburg.

KLEMM, M. 1988. Enzymelektrophoretische, morphometrische und faunistisch-ökologische Untersuchungen an Quellschnecken der Gattung Bythinella aus dem nördlichen und mittleren Schwarzwald (Mollusca, Prosobranchia, Bythinellidae). MS Thesis, University of Tübingen.

KÖNIGSSON, L.-K. 1968. The holocene history of the Great Alvar of Öland. Acta phytogeogr. suec., 55, 1-172.

LAVIE, B. AND NEVO, E. 1986. Genetic diversity of marine gastropods: contrasting strategies of Cerithium rupestre and C. scabridum in the Mediterranean Sea. Mar. Ecol. Prog. Ser., 28, 99-102.

LESICA, P., LEARY, R. F., ALLENDORF, F. W. AND BILDERBACK, D. E. 1988. Lack of genic diversity within and among populations of an endangered plant, Howellia aquatilis. Conserv. Biol., 2, 275-282.

LEWontin, R. C. 1974. The Genetic Basis of Evolutionary Change. Columbia University Press, New York.

LOVELESS, M. D. AND HAMRICK, J. L. 1984. Ecological determinants of genetic structure in plant populations. Ann. Rev. Ecol. Syst., 15, 65-95. 
MATHER, K. 1973. Genetical Structure of Populations. Chapman \& Hall, London.

MAYR, E. 1963. Animal Species and Evolution. Belknap Press, Cambridge, Mass.

NEI, M. 1972. Genetic distance between populations. Am. Nat., 106, 283-292.

NE1, M. 1987. Molecular Evolutionary Genetics. Columbia University Press, New York.

NEI, M. AND LI, W.-H. 1975. Probability of identical monomorphism in related species. Genet. Res., Cambridge, $26,31-43$.

NEI, M., MARUYAMA, T. AND CHAKRABORTY, R. 1975. The bottleneck effect and genetic variability in populations. Evolution, 29, 1-10.

NEUCKEL, W. 1981. Zu Aktivitätsregelung und Wasserhaushalt von Chondrina avenacea (Bruguiere, 1792), einer Felsen bewohnenden Landlungenschnecke. PhD Thesis, University of Basel.

Nevo, E., BEILES, A. AND BEN-SHLOMO, R. 1984. The evolutionary significance of genetic diversity: ecological, demographic and life-history correlates. Lecture Notes in Biomathematics, 53, 13-213.

PROSCHWITZ, T.V. 1977. Intressanta fynd av landsnäcka på Kinnekulle. Fauna och flora, 72, 189-192.

REES, W. 1965. The aerial dispersal of Mollusca. Proc. Malac. Soc. Lond., 36, 269-282.

ROSÉN, E. 1982. Vegetation development and sheep grazing in limestone grasslands of south Öland, Sweden. Acta phytogeogr. suec., 72, 1-108.

SCHLEGEL, M. 1985. Comparative study of allozyme variation in eight species of hypotrichous ciliates (Polyhymenophora, Ciliphora). Z. zool. Syst. Evolut.-forsch., 23, 171-183.

SCHLESCH, H. 1958. Über das isolierte Vorkommen von Chondrina clienta auf Öland und Gotland und anderer südöstlicher Landmollusken in der ostbaltischen Fauna. Arch. Moll., 87, 45-52.

SCHMID, G. 1929. Endolithische Kalkflechten und Schneckenfrass. Biol. Zentralbl., 49, 28-35

SELANDER, R. K. AND HUDSON, R. O. 1976. Animal population structure under close inbreeding: the land snail Rumina in southern France. Am. Nat., 110, 695-718.
SELANDER, R. K. AND KAUFMAN, D. W. 1973. Self-fertilization and genetic population structure in a colonizing land snail Proc. Natl Acad. Sci. USA, 70, 1186-1190.

SELANDER, R. K., KAUFMAN, D. W. AND RALIN, R. S. 1974 Self-fertilization in the terrestrial snail Rumina decollata. Veliger, 16, 265-270.

SELANDER, R. K. AND OCHMAN, H. 1983. The genetic structure of populations as illustrated by Molluscs. In Rattazzi, M C., Scandalios, J. G. and Whitt, G. S. (eds.) Isozymes: current topics in biological and medical research, Vol. 10, Genetics and Evolution, Alan R. Liss, New York, pp. 93123.

SELANDER, R. K., SMITH, M. H., YANG, S. Y., JOHNSON, W. E. \& GENTRY, J. B. 1971. Biochemical polymorphism and systematics in the genus Peromyscus. I, Variation in the old-field mouse Peromyscus polionotus. Studies in Genetics VI, University of Texas Publ. 7103, 49-90.

SELANDER, R. K. AND WhitTAM, T. S. 1983. Protein polymorphism and the genetic structure of populations. In $\mathrm{Nei}$ M. and Koehn, R. K. (eds.) Evolution of Genes and Proteins. Sinauer Ass. Inc., Sunderland, Massachusetts, pp. 89-114.

SHAW, C. R. AND PRASAD, R. 1970. Starch gel electrophoresis of enzymes - a compilation of recipes. Biochem. Gen., 4 297-320.

TOMLINSON, J. 1966. The advantages of hermaphroditism and parthenogenesis. J. Theor. Biol., 11, 54-58.

TOMPA, A. S. 1984. Lands snails (Stylommatophora). In Tompa, A. S., Verdonk, N. H. and van den Biggelaar, J. A. M. (eds.) The Mollusca, Vol. 7, Reproduction, Academic Press, New York, pp. 47-140.

WALDÉN, H. W. 1984. Sveriges landmollusker-en artlista med kommentarer. Fauna och flora, 79, 29-43.

WALDÉN, H. W. 1986. A comprehensive account of the Late Quaternary Land Mollusca in Scandinavia. Malakol. Abhand. Dresden, 11, 105-133.

williamson, H. 1981. Island Populations. Oxford University Press.

WOOL, D. 1987. Differentiation of island populations: a laboratory model. Am. Nat., 129, 188-202. 